\title{
Michat Zaremba
}

\section{Problemy regionalne Bliskiego i Dalekiego Wschodu}

[recenzja książki Współczesny regionalizm Bliskiego i Dalekiego

Wschodu]

\section{Regional problems of the Middle and Far East}

[book review Współczesny regionalizm Bliskiego i Dalekiego Wschodu]

\section{Региональные проблемы Ближнего и Дальнего Востока}

[рецензия книги Współczesny regionalizm Bliskiego i Dalekiego Wschodu]

K

siążka Współczesny regionalizm Bliskiego i Dalekiego Wschodu jest regionalnych Bliskiego i Dalekiego Wschodu. Opracowanie zostało wydane w 2019 roku w Toruniu przez Wydawnictwo Adam Marszałek, liczy 157 stron i zawiera dziewięć artykułów poprzedzonych Wstępem redaktorów.

Regionalizm, wokół którego koncentrują się autorzy, jest pojmowany szeroko - nie tylko jako forma współpracy politycznej i gospodarczej państw $\mathrm{w}$ danym regionie, ale jako spectrum regionalnych problemów i zjawisk zachodzących w regionie Bliskiego i Dalekiego Wschodu. Podjęte przez autorów zagadnienia są nie tylko ważne i interesujące ale - przynajmniej po części - przedstawiają problemy, których świadomość w Polsce wciąż jest (poza gronem specjalistów) relatywnie niewielka. Publikacja stara się tę lukę wypełnić i stanowi ona doskonałe opracowanie nie tylko dla badaczy, ale również dla decydentów i wszystkich osób interesujących się tą częścią świata. 
Publikację otwiera artykuł autorstwa Bogusława Packa oraz Karoliny Rak, zatytułowany „Migracje jako jedno z wyzwań państw azjatyckich”. Podjęty przez autorów problem jest ważny, a jego znaczenie będzie zapewne wzrastać w przyszłości, do czego przyczyniać się będą nie tylko czynniki społeczno-ekonomiczne, ale również m.in. zmiany klimatyczne. Autorzy na początku definiują i kategoryzują zjawisko migracji oraz pokrótce przedstawiają specyfikę migracji azjatyckiej. W kolejnej części autorzy słusznie skupiają się na czynnikach demograficznych oraz dochodowych, jako głównych determinantach migracji. Jest to bardzo ciekawa część, zawierająca wiele danych statystycznych oraz interesujących wniosków. Pewien niedosyt wywołuje fakt, że tytułowy problem został potraktowany dość skrótowo i zdecydowanie mógłby zostać pogłębiony. Artykuł stanowi przyczynek do dalszych refleksji i dyskusji na temat migracji i jej wpływu na poszczególne państwa i rejony.

Kolejny artykuł autorstwa Macieja Szczurowskiego skupia się na analizie mitów politycznych współczesnej Azji. Autor słusznie zauważa, że często nie docenia się znaczenia mitów, choć pełnią one istotną rolę w polityce. Praca ta ma ogromny walor informacyjny i przedstawia wysoką wartość analityczną, a sam autor interesująco zarysowuje i interpretuje megatrendy cywilizacyjne. Nawet jeśli część procesów, które analizuje autor, została potraktowana zbyt powierzchownie, to nie można odmówić mu erudycji i wyciągnięcia ciekawych wniosków.

Patryk Piotr Madej z kolei przygląda się problemowi separatyzmu cypryjskiego w jego wielowymiarowym aspekcie. Za cel autor przyjmuje identyfikację konsekwencji separatyzmu obecnego na Cyprze. Na podstawie tak określonego celu fomułuje interesującą tezę: głównym czynnikiem powodującym pojawienie się oraz wzrost tendencji separatystycznych na wyspie są nie tyle napięcia wewnętrzne, co działalność państw trzecich. $\mathrm{Na}$ początku autor dokonuje krótkiego wprowadzenia historycznego i charakterystyki separatyzmu cypryjskiego. Ta część ma dużą wartość informacyjną i poznawczą, szczególnie dla osób niezaznajomionych ze złożonością tego problemu. W kolejnej części autor analizuje, jak separatyzm przekłada się na gospodarkę wyspy, w tym przede wszystkim turystykę. Autor bezpośrednio nie weryfikuje tezy zawartej w tekście, niemniej dość jasno z wywodu wynika, że działalność innych państw - przede wszytkim naturalnie Grecji i Turcji 
- istotnie wpływa na separatyzm cypryjski. Praca z pewnością może być przyczynkiem do dalszych badań i refleksji w tym temacie.

Dwa kolejne teksty nie są bezpośrednio związane z kwestiami regionalizmu czy też problemów regionalnych na Bliskim i Dalekim Wschodzie. Stanowią one jednak interesujące studia interakcji kulturowych między Orientem i Okcydentem.

Pierwszy z nich, autorstwa Olgi Łozińskiej, przedstawia działaność włoskich Instytutów Kultury (Instituto Italiano di Cultura) jako jednego z głównych narzędzi włoskiego soft power w Japonii. Są to kwestie niezwykle istotne, gdyż rola soft pawer w polityce systematycznie wzrasta - narzędzi miękkiej siły używają już nie tylko kraje europejskie, ale coraz częściej i śmielej kraje azjatyckiej. Ogromne zainteresowanie kulturą Chin, Japonii czy Korei Południowej jest tego najlepszym przykładem.

W swojej pracy autorka ciekawie przedstawia historię Instytutów Kultury, celów, dla których zostały powołane i ich bieżącej działalności. Największa wartością pracy jest to, że dobitnie ukazuje rolę i znaczenie soft power we współczesnym świecie. Stanowi to również bardzo cenną lekcję dla Polski: w jaki sposób można promować kraj i przy okazji realizować swoje cele polityczne czy gospodarcze.

Z kolei artykuł Agnieszki Esin Lesiczki opisuje problemy nauczania języka tureckiego w Czechach i na Słowacji. Praca ma przede wszystkim walor informacyjny i prezentuje historię nauczania tego języka u naszych południowych sąsiadów oraz perspektywy jego rozwoju.

Adrianna Czarnecka w kolejnym opracowaniu porusza problem kobiecych jednostek YPJ w walce z tak zwanym Państwem Islamskim. Autorka swoim tekstem porusza istotną, dotychczas relatywnie rzadko podnoszoną kwestię: rolę kobiecych jednostek w walce z ISIS. Autorka stawia i weryfikuje dwie hipotezy: (1) kobiety odegrały istotną rolę w czasie walk z islamistami oraz (2) Kurdyjki zyskały poczucie tożsamości oraz przełamały tradycyjne role płciowe. Na podstawie przeprowadzonych analiz obie hipotezy zostały potwierdzone.

Tekst ten, poza ogromym walorem poznawczym, wypełnia także lukę w wiedzy o walkach z Państwem Islamskim. Kurdyjki przyczyniły się nie tylko do zwycięstwa nad ISIS, ale również do zrewidowania utartych opinii o Bliskim Wschodzie i muzułmankach. 
W kolejnym artykule Grażyna Strnad analizuje szczyty międzykoreańskie w czasie prezydentury Moon Jae Ina. Momentem przełomowym najnowszych stosunków między obiema Koreami były Igrzyska Olimpijskie, odbywające się w Pjongczangu w 2018 roku. W ciągu kilku miesięcy odbyły się aż trzy szczyty międzykrajowe i doszło do spotkania Kim Dzong Una z Moon Jae Inem. W rezultacie tych spotkań podpisano oficjalne deklaracje zawierające m.in. zapisy o chęci utrzymania pokoju na Półwyspie Koreańskim czy pogłębianiu dalszej współpracy. Praca ta jest jedną z ciekawszych w recenzowanej monografii. Wciąż relatywnie mało jest opracowań naukowych poświęconych problemom obu Korei, które przybliżają sytuację obecną na półwyspie.

Jacek Knopek w swojej pracy koncentruje się na społecznościach polskich w obszarze Półwyspu Arabskiego. Autor słusznie zauważa, że choć kontakty dawnej Rzeczpospolitej z Turcją były częste i intensywne, stosunki z innymi krajami muzułmańskimi, w tym na Półwyspie Arabskim, praktycznie nie istniały. Również po zakończeniu I wojny światowej i odzyskaniu przez Polskę niepodległości intensywność kontaktów, mimo pewnych działań, nie zwiększyła się. Sytuacja zmieniła się dopiero w latach 70. XX wieku, gdy na szeroką skalę rozwijał się na Półwyspie przemysł naftowy i rósł popyt na wysokiej klasy specjalistów. Obecnie polska diaspora w rejonie Półwyspu Arabskiego to przede wszytkim osoby zawodowo związane $\mathrm{z}$ regionem lub te, które założyły tam rodziny - przy czym naturalnie jedno nie wyklucza drugiego. Mimo że tamtejsze skupiska Polaków są względnie małe i „nowe”, to wykazują wysoki poziom samoorganizacji na tle społeczności polskich w innych krajach muzułmańskich.

Ostatni artykuł autorstwa Katarzyny Ciepieli przedstawia ostatnie wybory prezydenckie w „trzeciej demokracji świata” - Indonezji. Uchodzą one za największe wybory bezpośrednie na świecie. Z jednej strony praca ta uzmysławia jak jeszcze młodą i niestabilną demokracją jest Indonezja oraz jak wielkie wpływy mają grupy religijne oraz elity rządzące. Z drugiej strony, autorka doskonale zarysowuje, jaki wpływ na współczesne demokracje mają media społecznościowe - i to niestety w negatywnym aspekcie, przede wszystkim jako miejsca powstania i rozprzestrzeniania się fake newsów. Artykuł nie tylko ciekawie przedstawia funkcjonowanie demokracji indonezyjskiej i jej problemy, ale również może stanowić przyczynek do szerszych dyskusji 
nad stanem i dysfunkcjami współczesnej demokracji oraz możliwości jej usprawnienia.

Podsumowując, można z całą pewnością stwierdzić, że recenzowana praca odznacza się bardzo wysokimi walorami analitycznymi i informacyjnymi. Czytelnik otrzymał solidny i interesujący przegląd wybranych problemów regionalnych Bliskiego i Dalekiego Wschodu. Lektura jest nie tylko ubogacająca i poszerzająca wiedzę, ale może stanowić inspirację do dalszych badań i refleksji.

DR MICHAŁ ZAREMBA

Instytut Ekonomii

Wydział Ekonomiczno-Socjologiczny

Uniwersytet Łódzki

ul. Rewolucji 1905 r. nr 41/43, 90-214 Łódź

michal.zaremba@uni.lodz.pl

\section{Bibliografia}

Marszałek-Kawa, J., Kądzielawski, G. (red.). (2019). Współczesny regionalizm Bliskiego i Dalekiego Wschodu. Toruń: Wydawnictwo Adam Marszałek. 